\title{
How effective is river restoration in re-establishing groundwater-surface water interactions? - A case study
}

\author{
A.-M. Kurth ${ }^{1,2}$, C. Weber ${ }^{3}$, and M. Schirmer ${ }^{1,2}$ \\ ${ }^{1}$ Department of Water Resources and Drinking Water, Eawag, Swiss Federal Institute of Aquatic Science and Technology, \\ Überlandstrasse 133, 8600 Dübendorf, Switzerland \\ ${ }^{2}$ The Centre of Hydrogeology and Geothermics (CHYN), University of Neuchâtel, Rue Emil-Argand 11, \\ 2000 Neuchâtel, Switzerland \\ ${ }^{3}$ Department of Surface Waters, Eawag, Swiss Federal Institute of Aquatic Science and Technology, Seestrasse 79, \\ 6047 Kastanienbaum, Switzerland
}

Correspondence to: A.-M. Kurth (anne-marie.kurth@eawag.ch)

Received: 9 December 2014 - Published in Hydrol. Earth Syst. Sci. Discuss.: 23 January 2015

Revised: 28 April 2015 - Accepted: 14 May 2015 - Published: 9 June 2015

\begin{abstract}
In this study, we investigated whether river restoration was successful in re-establishing groundwater-surface water interactions in a degraded urban stream. Restoration measures included morphological changes to the river bed, such as the installation of gravel islands and spur dykes, as well as the planting of site-specific riparian vegetation. Standard distributed temperature sensing (DTS) and novel active and passive DTS approaches were employed to study groundwater-surface water interactions in two reference streams and an experimental reach of an urban stream before and after its restoration. Radon-222 analyses were utilized to validate the losing stream conditions of the urban stream in the experimental reach. Our results indicated that river restoration at the study site was indeed successful in increasing groundwater-surface water interactions. Increased surface water downwelling occurred locally at the tip of a gravel island created during river restoration. Hence, the installation of in-stream structures increased the vertical connectivity and thus groundwater-surface water interactions. With the methods presented in this publication, it would be possible to routinely investigate the success of river restorations in re-establishing vertical connectivity, thereby gaining insight into the effectiveness of specific restoration measures. This, in turn, would enable the optimization of future river restoration projects, rendering them more cost-effective and successful.
\end{abstract}

\section{Introduction}

In recent years, significant efforts have been taken worldwide to restore degraded rivers and streams (Filoso and Palmer, 2011; Gilvear et al., 2012; Haase et al., 2013), in order to protect ecosystem health, incorporate sustainable flood protection, and preserve valuable water resources (Andrea et al., 2012; Palmer et al., 2005; Wortley et al., 2013).

The aim of river restoration is often stated as achieving the highest possible ecological status or re-establishing the natural function of streams to a pre-degraded state (EU WFD, 2000; Maher, 2009; Swiss Water Protection Act 814.20). This includes the recreation of a natural river morphology and the provision of habitats for native flora and fauna, while maintaining groundwater-surface water interactions.

The latter, in particular, is of paramount importance with regard to the natural functioning of streams; the interaction between groundwater and surface water controls the availability of nutrients in the hyporheic zone (Fuller and Harvey, 2000; Gooseff et al., 2002; Butturini et al., 2003), impacts water temperature (Bencala, 2005; Hannah et al., 2009; Norman and Cardenas, 2014) and quality (Boulton et al., 1998; Findlay, 1995; Fuller and Harvey, 2000; Trauth et al., 2015), and thus influences ecosystem functioning (Boulton et al., 1998; Malard et al., 2002; Thorp et al., 2006) and health (Wondzell, 2011).

Many river restoration efforts focus on the reestablishment of longitudinal and lateral connectivity 


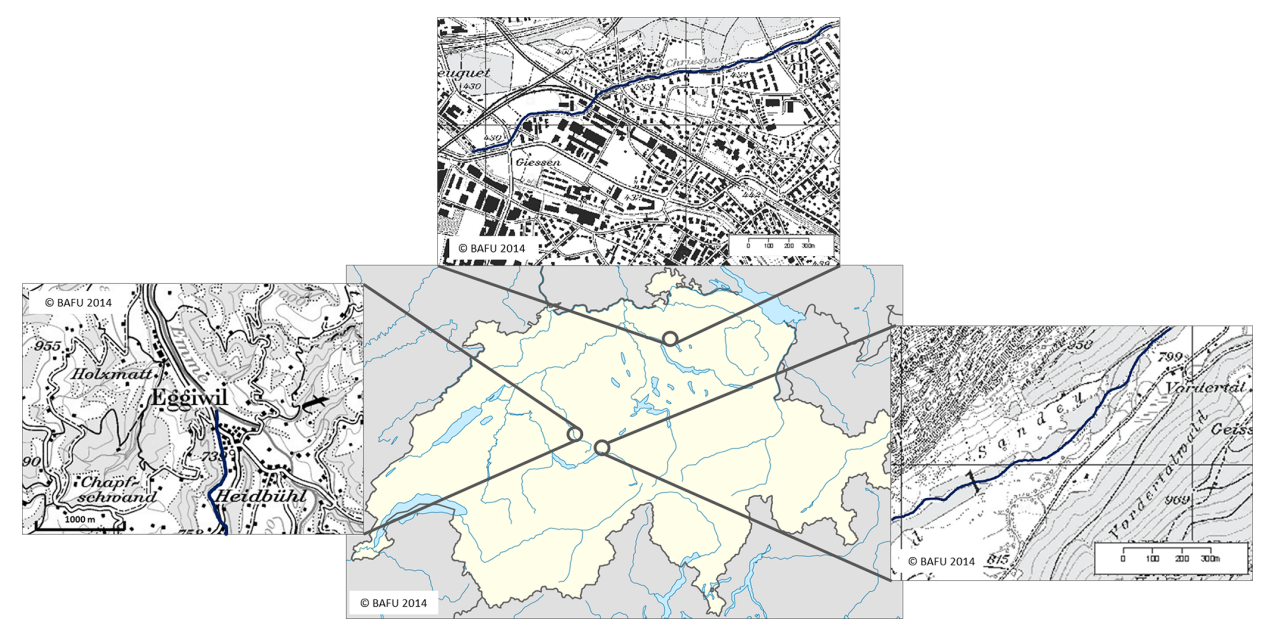

Figure 1. Locations of the Chriesbach (top), the Röthenbach (left), and the Urbach (right) in Switzerland.
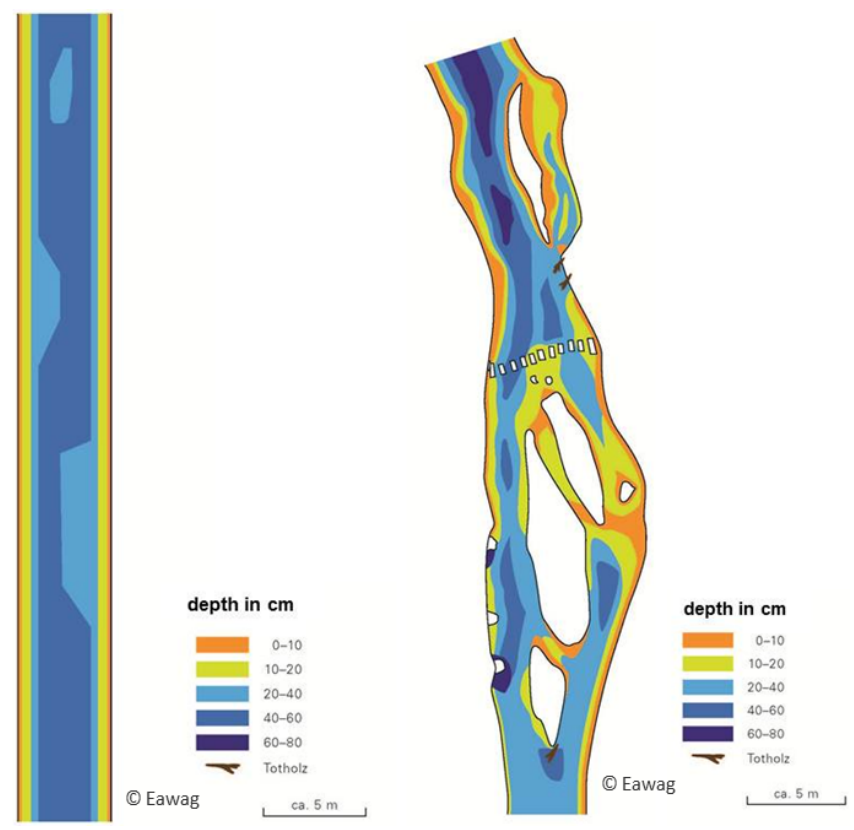

Figure 2. Stream morphology of the Chriesbach before and after river restoration, Eawag ${ }^{\circledR}$.

and appearance, rather than vertical connectivity (Mendiondo, 2008; Filoso and Palmer, 2011; Sudduth et al., 2011; Kurth and Schirmer, 2014), a fact that might explain the often cited failure of river restoration with respect to ecosystem functioning (Louhi et al., 2011; Sudduth et al., 2011; Violin et al., 2011). Clearly, it is not sufficient to change the appearance of a short stretch of a stream to restore the complex interplay of riverine ecosystems and their surroundings. Hence, more and more projects are taking a more holistic approach to river restoration (Kurth and Schirmer, 2014).
The success of these river restorations may be evaluated with respect to abiotic parameters, such as hydromorphological characteristics; biotic parameters, such as biodiversity; or socioeconomic aspects, e.g. the recreational value (Jähnig et al., 2011). Most river restoration success evaluations, however, seem to focus on biotic parameters (Wortley et al., 2013). Reports regarding the success in re-establishing the vertical connectivity in streams could not be found.

We were therefore interested in evaluating the hydrogeological success of a restoration project which had been planned by a multidisciplinary team of biologists, chemists, civil engineers, ecologists, hydraulic engineers, hydrogeologists, physicists, and social scientists. We define hydrogeological success as an increase in vertical connectivity along the restored reach of the stream. This will be indicated by an increase in groundwater-surface water interactions, provided that groundwater and surface water were connected prior to anthropogenic interference. Ideally, a spatial variability in high and low exchange rates will be reached for the benefit of the aquatic ecosystems.

In this paper we discuss the results gained from investigations with distributed temperature sensing (DTS), a fibreoptical method for temperature measurements along a glass fibre (Kurth et al., 2013; Selker et al., 2006a, b). Fibre-optic cables were either installed directly on top or in ca. $0.4 \mathrm{~m}$ depths of the streambed. This enabled us to determine the groundwater-surface water interactions under gaining and losing stream conditions. Additionally, hydrogeological conditions were investigated in the vicinity of the restored stream reach, and losing stream conditions verified with radon-222 analyses. Apart from investigating a stream before and after its restoration, experiments were performed in natural and near-natural reference streams. "Natural" and "near-natural" thereby refer to the condition of the streambed as being unaffected or only mildly affected by anthropogenic alterations. Thus, we tested the hypothesis that the vertical connectiv- 
ity, and therefore groundwater-surface water interactions, indeed improves after river restoration. We conclude with an outlook on the application of the described DTS measurement approach and recommendations for restoration practice based on our insights.

\section{Material and methods}

\subsection{Study sites}

In our study we evaluated three perennial Swiss streams: the Chriesbach, the Röthenbach, and the Urbach (Fig. 1). Apart from similarities in their dimensions and discharge, they vary in their state of morphological degradation: while the Urbach is a natural alpine stream, the Röthenbach and the Chriesbach are mildly to severely degraded streams of the Swiss Plateau in rural and urban areas, respectively. The Urbach and the Röthenbach, thereby, are reference streams to evaluate whether the restoration of the Chriesbach recreated conditions resembling either a natural or a near-natural stream. "Natural" and "near-natural" thereby refers to the streams' morphology and the groundwater-surface water interactions. Both parameters were tested prior to site selection following guidelines by the Swiss Federal Office for the Environment and by manually evaluating the temperature distribution in the streams, respectively.

Flowing between gentle-sloped meadows and steep rock walls, the Urbach is a braided stream with various main and side channels and in-stream islands (Doering et al., 2012). In spite of upstream hydropower production and the installation of stone crib walls as flood protection measures in the meadows, the Urbach has maintained its natural river morphology due to the extensive intermediate catchment between study site and the retaining lake of the hydropower production plant. Hence, it was selected as a reference for presumably natural groundwater-surface water interactions.

Although having been lowered and straightened led to a rather uniform stream width, the Röthenbach still has a naturally varying water depth and flow velocities. The stream is impacted by diffuse manure inflow into the stream, by discharge of warm water from power production in a nearby sawmill, and by a significant drawdown due to water abstraction in the surrounding areas in summer. Nevertheless, due to initial investigations of the water temperature distribution in the stream, groundwater-surface water interactions in the Röthenbach were assumed to be near-natural in winter.

Originally a meandering stream, the Chriesbach was lowered and channelized in the 1910s and 1970s, leading to a loss of in-stream structures and habitats, and causing severe degradation. Hence, between 2006 and 2014, $900 \mathrm{~m}$ of the Chriesbach was restored: the channel was widened, shores levelled, and water depth and width varied (Fig. 2). In-stream islands and ponds were created and site-specific riparian vegetation planted. Even though these measures hardly reverse the severe effect of channelization and lowering, the Chriesbach now has a more natural river morphology. The study site of the Chriesbach investigated in this study was restored in the autumn and winter of 2013/2014.

\subsection{Water temperature measurements with distributed temperature sensing (DTS)}

Raman-based DTS is a fibre-optic method for temperature measurements along a glass fibre into which laser light pulses are injected (Selker et al., 2006a; Tyler et al., 2009). Inside the glass fibre, the laser light's photons are backscattered either inelastically or elastically, i.e. with or without a change in their energy, depending on the temperature-sensitive energy level of the glass molecules with which the photons interact. The DTS instrument then analyses the energy and the time of arrival of the elastically and inelastically backscattered photons, the so-called "Stokes" and "anti-Stokes" signal, and calculates the temperature for each section, e.g. every metre, of the glass fibre. Thus, the temperature of the entire length of the glass fibre is measured simultaneously. Careful calibration of the DTS instrument with reference baths thereby improves the accuracy of the measurement. It is generally assumed that the temperature of the fibre-optic cable equals the surrounding temperature (Tyler et al., 2009), e.g. the surface water temperature.

DTS technology is very convenient in hydrogeology, as the temperature of long stretches of streams can be determined simultaneously and groundwater upwelling into streams can be monitored due to differences in their temperatures (Anderson, 2005; Briggs et al., 2012; Tyler et al., 2009). DTS measurements may be performed as passive and active measurements. Passive measurements are standard temperature measurements along the glass fibre (Steele-Dunne et al., 2010). In active measurements, on the other hand, the metal components of the fibre-optic cable, e.g. copper or steel wires, are heated by applying an electrical current through them (Read et al., 2014). This allows retrieving information on the cooling behaviour of the fibre-optic cable, indicating areas with lower or higher rates of water flow over the cable. Both active and passive DTS measurements were employed in this study.

\subsection{Radon-222 measurements}

Radon-222 is a product of the decay of radium-226 in the decay chain of uranium-238 to lead-206. As decaying uranium238 is present in the subsurface, groundwater is generally enriched in radon-222. Surface water, on the other hand, has lower radon-222 levels, due to rapid degassing of radon222. Hence, radon-222 is an ideal tracer for groundwater upwelling in surface waters (e.g. Cartwright et al., 2014; Cook, 2013; Hoehn et al., 1992). A detailed description of the experimental set-up is described in the experimental section. 


\subsection{Experimental set-up in the field}

DTS measurements were performed with an Agilent DTS N4386A and a Sensornet Oryx ${ }^{\circledR}$ DTS, with a sampling interval of $1 \mathrm{~m}$, and a spatial resolution of $1.5 \mathrm{~m}$, respectively. Both instruments were calibrated with the same procedure, including constantly stirred ice and hot water baths and dispersion, slope and offset corrections. Additionally, postmeasurement drift and offset correction were applied. We employed a heatable multimode BRUsens fibre-optic cable (BRUGG AG, Switzerland) with copper and steel wires for heatability. As it was impossible to maintain a temperature reference bath in the field, a $200 \mathrm{~m}$ section of the cable exposed to air was used as reference and the cable temperature determined with Hobo TidbiTs $^{\circledR}$ temperature probes. Two additional temperature probes were installed in the water at the beginning and the end of the fibre-optic cable submerged in the streams. Hobo TidbiTs ${ }^{\circledR}$ measurement intervals were matched to the DTS measurement integration time, i.e. 3 or $15 \mathrm{~min}$. Measurements were performed on days with low flow and no precipitation, on the coldest days in winter (Chriesbach, Röthenbach) and a moderately warm day in summer (Urbach). DTS measurements at the Urbach could not be performed in winter, as the valley is closed during winter due to an elevated risk of avalanches.

All measurements in the Urbach and the Röthenbach were passive measurements. At the Chriesbach site, measurements were passive before (2013) and after restoration (2014), and active after restoration (2014). For passive measurements at the Urbach, the Röthenbach and the Chriesbach prior to its restoration, the fibre-optic cables were fixed on the streambed; for passive $(\mathrm{P})$ and active $(\mathrm{A})$ measurements at the Chriesbach after restoration the fibre-optic cable was buried (B) with a plough at a depth of about $0.4 \mathrm{~m}$ within the streambed (PAB approach) (Fig. 3). The PAB approach is a new method for the detection of groundwater-surface water interactions in losing stream conditions (Kurth, 2015). The periodic heating of the buried fibre-optic cable provides an insight into the spatial distribution of surface water infiltration into and groundwater exfiltration out of the streambed. These measurements could not be performed prior to restoration, as the inserted fibre-optic cable would have been damaged by the mechanical diggers remodelling the streambed during river restoration. During active measurements, the metal components of the fibre-optic cable were heated with a current of $10 \mathrm{~A}\left(2.48 \mathrm{~W} \mathrm{~m}^{-1}\right)$ for $30 \mathrm{~min}$ twice a day. The cooling rate of the fibre-optic cable was calculated as a temperature change per minute. To avoid possible correlations between the temperature of the fibre-optic cable and the cooling rate of the fibre-optic cable in a way that warmer sections of the cable heat up more strongly, the cooling rate was investigated in the temperature range of 15.9 to $16.1^{\circ} \mathrm{C}$ in steps of $0.1^{\circ} \mathrm{C}$. This temperature range was selected as it had the highest number of measurement points.

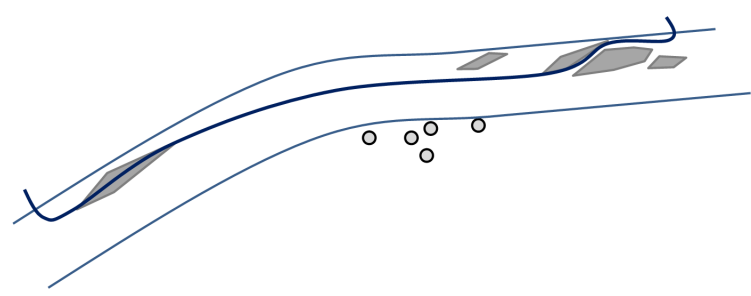

Figure 3. Overview over the study reach of the restored Chriesbach. The light blue lines delineate the Chriesbach, albeit without following the exact contour of the shoreline. The light grey structures represent in-stream gravel islands; the circles represent piezometers. The dark blue line shows the approximate position of the fibre-optic cable.

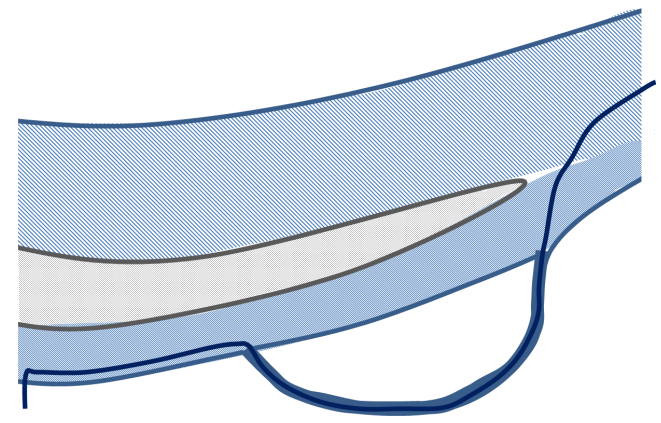

Figure 4. Overview over the study reach of the Urbach. The wider spaced blue shading represents the main channel, the tighter shading the side channel, and the full blue colour the drainage ditch. The grey-shaded area delineates the in-stream island between the main and side channel, the dark blue line the approximate position of the fibre-optic cable.

Measurements in the Urbach were performed with the fibre-optic cable being passed through three areas: a side channel (cable sections 140 to $188 \mathrm{~m}$ ), a drainage ditch draining the surrounding meadows (cable sections 194 to $266 \mathrm{~m}$ ), and the main channel of the Urbach (cable sections 269 to $327 \mathrm{~m}$ ) (Fig. 4). The drainage ditch was measured to provide insight into the local groundwater temperature, as it was assumed that it was mainly fed by groundwater that day.

At the Chriesbach site, groundwater temperature and the groundwater level were measured every $15 \mathrm{~min}$ with a temperature logger (STS Switzerland ${ }^{\circledR}$ ) situated in around $3 \mathrm{~m}$ depth of a piezometer situated next to the investigated reach of the stream (Fig. 3).

Radon-222 measurements for the detection of groundwater inflow into the Chriesbach were performed after river restoration with a RAD7 instrument (Niton-Durridge, USA). Water samples were taken shortly before analysis from surface water and groundwater at the restored site and from an unrestored reference site further upstream. Groundwater samples were also taken from piezometers at the restored site with a Gardena ${ }^{\circledR}$ jet pump with a pumping rate of $0.9 \mathrm{~L} \mathrm{~s}^{-1}$. The piezometers were flushed for $15 \mathrm{~min}$ and water samples 

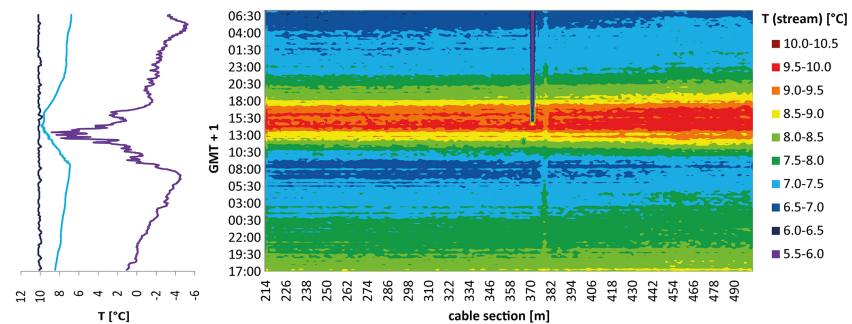

Figure 5. Air (purple), stream (light blue) and groundwater (dark blue) temperature (line diagram, left side) and surface water temperatures (colour plot, right side) of the Chriesbach before river restoration, on 13-15 March 2013. The $x$ axis of the colour plot shows the sections of the fibre-optic cable in metres; the colours represent the surface water temperatures in ${ }^{\circ} \mathrm{C}$. Thereby, each coloured line on the $x$ axis, from cable section 214 to $501 \mathrm{~m}$, represents one measurement. The $y$ axis states the time of the measurements.

were taken from $6 \mathrm{~m}$ depths. Samples were taken early in the morning to prevent warming and degassing of the samples in the tubing. The tubing was checked for bubble formation prior to sampling. All sample bottles were triple-washed and samples taken without air inclusion. Comparative measurements with the Urbach and Röthenbach sites were not possible due to unavailability of the radon-222 detector.

\section{Results}

\subsection{Passive DTS water temperature measurements}

The surface water temperature profile of the Chriesbach was investigated before (Fig. 5) and after river restoration (Fig. 6). Hereby, the term "temperature profile" describes the longitudinal temperature distribution along the investigated section of the stream. During the data collection before river restoration, the air temperature varied between -5.3 and $8.8^{\circ} \mathrm{C}$ (Fig. 5, left side). The surface water temperature (Fig. 5, right side) closely followed the air temperature, varying between 6.4 and $9.9^{\circ} \mathrm{C}$. Groundwater temperatures ranged between 11.3 and $11.4{ }^{\circ} \mathrm{C}$ during the investigated period. Apart from two cable sections with elevated surface water temperatures at 372 and $379 \mathrm{~m}$, the surface water temperature distribution in the Chriesbach was relatively uniform, decreasing after sunset and increasing again in the morning.

The data collected after the restoration of the Chriesbach appeared to be rather different (Fig. 6). Here, air temperatures varied between 0.5 and $4.9^{\circ} \mathrm{C}$ and surface water temperatures ranged between 8.6 and $10.3{ }^{\circ} \mathrm{C}$. The surface water temperature reached its minimum and maximum in the morning and afternoon, respectively. However, the pattern is less distinct than in the pre-restoration data set. Surface water temperature anomalies were to be found around cable sections $299,357,372$, and $478 \mathrm{~m}$.
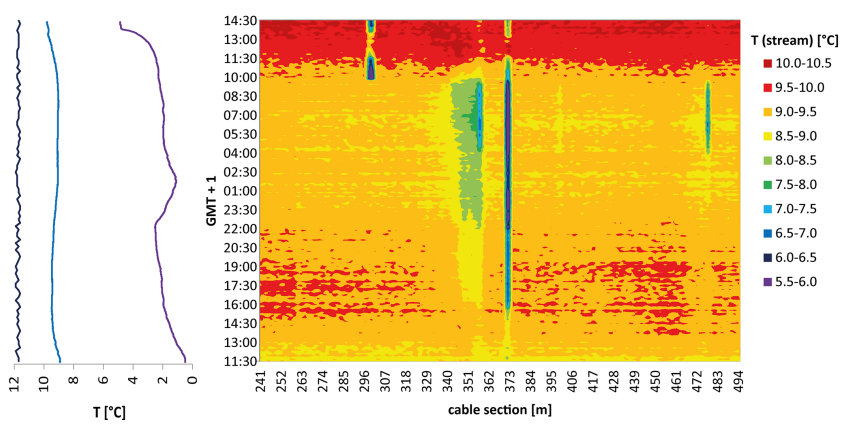

Figure 6. Air (purple), stream (light blue) and groundwater (dark blue) temperature (line diagram, left side) and surface water temperatures (colour plot, right side) of the Chriesbach after river restoration, on 28-29 November 2013. The $x$ axis of the colour plot shows the sections of the fibre-optic cable in metres; the colours represent the surface water temperatures in ${ }^{\circ} \mathrm{C}$. Each coloured line on the $x$ axis, from cable section 241 to $493 \mathrm{~m}$, represents one measurement. The $y$ axis states the time of the measurements.

The surface water temperature data from the Urbach, the natural reference site, was very diverse (Fig. 7). The air temperature ranged between $18.6^{\circ} \mathrm{C}$ in the late morning and $23.6^{\circ} \mathrm{C}$ in the afternoon. The surface water temperature in the side channel (cable sections 140 to $188 \mathrm{~m}$ ) closely followed the air temperature, ranging between 9.4 and $12.3^{\circ} \mathrm{C}$, as the fibre-optic cable was installed in a shallow part of the stream, which was exposed to the sun throughout the measurement. Surface water temperatures in the drainage ditch (cable sections 194 to $266 \mathrm{~m}$ ) ranged between $7.8^{\circ} \mathrm{C}$ in the late afternoon and $10.6^{\circ} \mathrm{C}$ around noon. Thereby, $7.8^{\circ} \mathrm{C}$ is assumed to represent the groundwater temperature in that area. The drainage ditch was partially exposed to sunlight between the morning and the early afternoon and completely shaded afterwards. The higher temperatures at cable section $247 \mathrm{~m}$ at the beginning of the measurement were caused by the fibre-optic cable being exposed to air. The surface water in the main channel (cable sections 269 to $327 \mathrm{~m}$ ) had water temperatures similar to the drainage ditch, ranging from $9.0^{\circ} \mathrm{C}$ in the morning to $10.7^{\circ} \mathrm{C}$ in the early afternoon. The stream was completely exposed to sunlight throughout the measurement period.

The data from the near-natural reference site, the Röthenbach (Fig. 8), differed strongly from the previously seen natural reference of the Urbach. Air temperatures ranged between -4.5 and $13.1^{\circ} \mathrm{C}$. Surface water temperatures closely followed the diurnal variations in air temperature, with the surface water temperature ranging from $1.2^{\circ} \mathrm{C}$ in the morning to a maximum of $7.6^{\circ} \mathrm{C}$. However, this maximum water temperature occurred exclusively around cable section $199 \mathrm{~m}$ and was constant throughout the measurement period. Around cable section $273 \mathrm{~m}$, the surface water temperature was elevated as well, but less pronounced and not as constant as around cable section $199 \mathrm{~m}$. With the exception 
Table 1. Radon-222 activities in $\mathrm{Bq} / \mathrm{m}^{3}$ in groundwater and surface water samples from the Chriesbach. Samples 4.2 and 5.2 are replicates of samples 4.1 and 5.1, taken 39 days after the first sampling event.

\begin{tabular}{lllc}
\hline$\#$ & Sample location & Type & Radon-222 activity $\left[\mathrm{Bq} \mathrm{m}{ }^{-3}\right]$ \\
\hline 1 & restored section, close to stream & groundwater & $3482 \pm 627$ \\
2 & restored section, close to piezometers & surface water & $517 \pm 246$ \\
3 & restored section, 2.5 m away from stream & groundwater & $5037 \pm 563$ \\
4.1 & restored section, 0.4 km upstream of investigated area & surface water & $411 \pm 169$ \\
4.2 & & & $90 \pm 104$ \\
5.1 & unrestored section, ca. 0.5 km upstream of investigated section & surface water & $1103 \pm 243$ \\
5.2 & & & $47 \pm 94$ \\
6 & unrestored section, ca. 0.55 km upstream of investigated section & surface water & $0 \pm 0$ \\
\hline
\end{tabular}
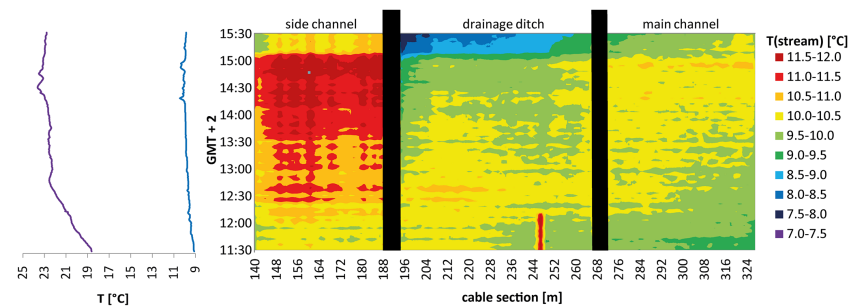

Figure 7. Air and stream reference temperature (line diagram, left side; purple and blue line, respectively) and surface water temperatures (colour plot, right side) of the Urbach on 3 September 2013. The $x$ axis of the colour plot shows the sections of the fibre-optic cable in metres; the colours represent the surface water temperatures in ${ }^{\circ} \mathrm{C}$. Thereby, each coloured line on the $x$ axis, from cable section 140 to $327 \mathrm{~m}$, represents one measurement. The $y$ axis states the time of the measurements.

of these two sections, the surface water temperature in the Röthenbach was very uniform. It decreased after sunset and increased around noon, following the air temperature with a delay of a few hours. This delay was due to the Röthenbach being in shadow until noon.

\subsection{Active and passive DTS measurements with the buried fibre-optic cable}

During passive (P) and active (A) DTS data acquisition with the buried (B) fibre-optic cable (PAB approach), surface water temperatures varied between 14.3 and $19.2^{\circ} \mathrm{C}$ (Fig. 9). The streambed temperatures, on the other hand, varied more strongly, ranging between 14.3 and $29.6^{\circ} \mathrm{C}$. The streambed temperature distribution, however, was not uniform. Maximum streambed temperatures occurred around cable sections 205 and $240 \mathrm{~m}$. Elevated and minimum streambed temperatures appeared around cable sections 45, 135, and $143 \mathrm{~m}$, but also, less pronounced, around cable sections 60, 70, 79, and $180 \mathrm{~m}$. In the other sections of the fibre-optic cable, streambed temperatures changed less throughout the day and night, varying only slightly between 15.4 and $16.5^{\circ} \mathrm{C}$, except during periods in which the fibre-optic cable was heated.

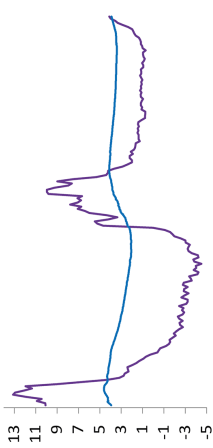

$\mathrm{T}\left[{ }^{\circ} \mathrm{C}\right]$

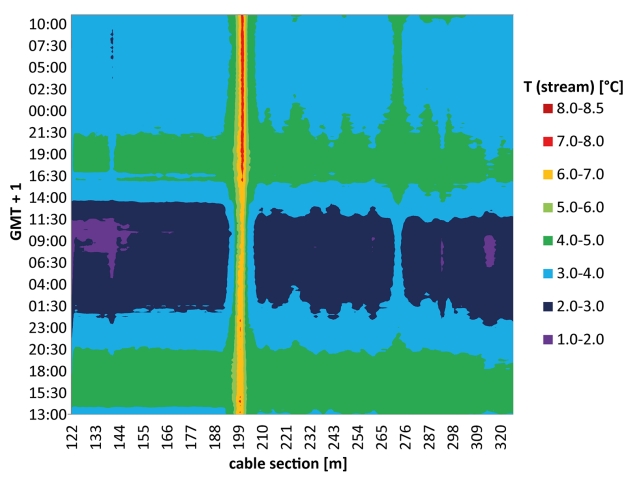

cable section $[\mathrm{m}]$
Figure 8. Air and stream reference temperature (line diagram, left side; purple and blue line, respectively) and surface water temperatures (colour plot, right side) of the Röthenbach on 17-19 February 2014. The $x$ axis of the colour plot shows the sections of the fibre-optic cable in metres; the colours represent the surface water temperatures in ${ }^{\circ} \mathrm{C}$. Thereby, each coloured line on the $x$ axis, from cable section 140 to $325 \mathrm{~m}$, represents one measurement. The $y$ axis states the time of the measurements.

The heating of the fibre-optic cable caused a rise in cable temperatures of between $1.3^{\circ} \mathrm{C}$ and $1.6 \mathrm{~K}$, depending on the initial temperature of the cable. In the section of maximum streambed temperatures, heating was more rapid and led to a slightly higher temperature difference $\left(\Delta T 1.6^{\circ} \mathrm{C}\right)$, than in the other sections $\left(\Delta T 1.3^{\circ} \mathrm{C}\right)$. The lowest cooling rate was seen at cable section $111 \mathrm{~m}$ (Fig. 10) in a shallow part of the stream with stagnant water, the highest cooling rate was seen at cable section $195 \mathrm{~m}$ at the tip of a gravel island. About $80 \%$ of cooling rates ranged between 0.082 and $0.086{ }^{\circ} \mathrm{C} \mathrm{min}^{-1}$.

\subsection{Radon-222 measurements}

The radon-222 activity in the surface water samples of the Chriesbach, obtained after its restoration, was very low (Table 1). Radon-222 activities in the Chriesbach ranged between 0 and $1103 \mathrm{Bqm}^{-3}$. In the nearby piezometers, radon222 activities were significantly higher, with values ranging between 3482 and $5037 \mathrm{Bqm}^{-3}$. Sample 5.1 had the high- 

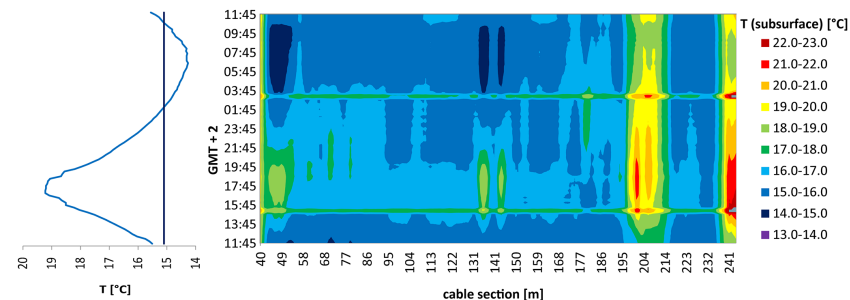

Figure 9. Surface water (light blue) and groundwater (dark blue) temperature (line diagram, left side) and streambed temperatures (colour plot, right side) in the Chriesbach streambed at about $0.4 \mathrm{~m}$ depth, as measured with a fibre-optic cable installed after river restoration on 3-4 July 2014. The $x$ axis of the colour plot shows the section of the fibre-optic cable in metres; the colours represent the streambed temperatures in ${ }^{\circ} \mathrm{C}$. Thereby, each coloured line on the $x$ axis, from cable section 40 to $243 \mathrm{~m}$, represents one measurement. The $y$ axis states the time of the measurements.

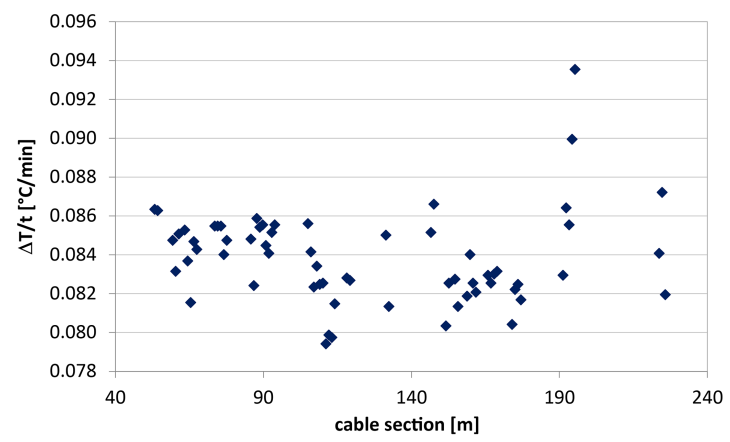

Figure 10. Cooling rates of cable sections with a temperature between 15.9 and $16.1^{\circ} \mathrm{C}$ determined at night in ${ }^{\circ} \mathrm{C} \mathrm{min}-1$.

est radon-222 activity of all surface water samples. However, this result could not be verified in a second sampling campaign. The radon-222 activity in the groundwater samples was significantly higher than in the surface water samples, and increased with increasing distance from the stream.

\section{Discussion}

In this study we investigated whether river restoration in an urban setting indeed enhanced the vertical connectivity in the stream and thus created conditions in which the ecosystem can, under given conditions, unfold its full potential.

The surface water temperature profile of the unrestored Chriesbach was very uniform along the investigated section of the stream. However, there were two cable sections at 372 and $379 \mathrm{~m}$ with slightly elevated surface water temperatures. The purple line visible after 3 p.m. on 14 March 2013, around cable section $372 \mathrm{~m}$ (Fig. 5), was caused by a sharp bend in the cable, a defect that was visible in the post-restoration data as well (Fig. 6). The slightly elevated surface water temperatures around cable section $379 \mathrm{~m}$ (Fig. 5) were due to algae and debris accumulating at this section of the fibre-optic ca- ble, possibly acting as a temperature buffer. These effects are always localized and are either detected during regular cable checks or, at the latest, during removal of the fibre-optic cable.

A similarly uniform surface water temperature profile was seen in the Urbach. The drainage ditch was groundwaterfed on the day of the experiment. The surface water temperature profile in the main channel was very similar to the drainage ditch, indicating that the main channel was mainly groundwater-fed in the investigated section of the stream. The slightly elevated surface water temperatures in the main channel were caused by the channel being fully exposed to the sunlight throughout the experiment, while the drainage ditch was shaded in the afternoon. Robinson and Doering (2013) observed a similar pattern of groundwater upwelling in the investigated section of the Urbach's main channel and groundwater-fed tributaries on the eastern side of the stream. Presumably groundwater upwelling occurred uniformly and on a large scale, as no localized regions of groundwater temperatures were observed in the main channel or the drainage ditch.

Localized groundwater upwelling, however, was observed in the Röthenbach. Here, groundwater upwelling occurred in discrete zones, in which surface water temperatures were constant or elevated throughout the experiment. In the zones with constant surface water temperatures, significant amounts of groundwater were infiltrating into the stream. Similar observations were made e.g. by Unland et al. (2013). In this context, significant means a groundwater inflow rate sufficient to maintain surface water temperature at a constant value equalling the groundwater temperature. In the zones with elevated surface water temperatures, groundwater was infiltrating, albeit not in significant volumes.

In the case of the Chriesbach, the results indicate that there was no groundwater upwelling in the investigated section of the stream, as the surface water temperature of the Chriesbach was ca. $2 \mathrm{~K}$ below the groundwater temperature and strongly varied with the daily temperature fluctuations. The surface water temperature profile of the Chriesbach after restoration was equally uniform in space as prior to its restoration, with four exceptions. The lower surface water temperatures around cable section $372 \mathrm{~m}$ were caused by the defect in the fibre-optic cable already seen in the data of the unrestored Chriesbach. The surface water temperature anomalies around cable sections 299 and $478 \mathrm{~m}$ were due to the fibre-optic cable being exposed to the air. The lower surface water temperatures around cable section $357 \mathrm{~m}$, on the other hand, were induced by the fibre-optic cable resting in a section of the stream with stagnant and very shallow water, which cooled down more rapidly than the rest of the stream.

Apart from these anomalies, the surface water temperature profile was very uniform in space. However, it was very uniform in time as well. There are several explanations for this behaviour: either the amount of groundwater infiltrating from further upstream increased due to river restoration, or the sig- 
nificantly lower variation in air temperature $\left(14.1^{\circ} \mathrm{C}\right.$ before restoration, $4.4^{\circ} \mathrm{C}$ after restoration) induced a much smaller change in the surface water temperature. Hydrogeological investigations at that time indicated that the Chriesbach was a losing stream in the investigated section, which confirmed that the homogenous surface water temperature profile was caused by the lower air temperature variations.

Radon-222 measurements in the restored Chriesbach and an unrestored reference section of the Chriesbach further upstream confirmed the losing conditions of the Chriesbach in the investigated section and indicated that no groundwater upwelling occurred upstream either.

The active DTS data with the fibre-optic cable buried at about $0.4 \mathrm{~m}$ depth indicated that most surface water downwelling occurred at cable section $195 \mathrm{~m}$, the tip of a gravel island newly created during restoration of the Chriesbach. Research by Shope et al. (2012) confirms this observation. The lowest downwelling was seen at cable section $111 \mathrm{~m}$, a section of the cable buried in a shallow pool of stagnant water at the side of the stream. Cooling rates in the other cable sections were rather uniform, which might be explained by the homogeneous sediment composition and a lack of in-stream structures in these stream sections. As the fibre-optic cable was only inserted in one of the gravel islands no conclusions may be drawn as to the surface water downwelling in the other gravel islands.

\section{Conclusions}

Success evaluations in river restoration are increasingly being employed to test whether restoration measures were successful in improving conditions for the ecosystem. Hydrogeological success, which influences ecological success as well, however, is not routinely investigated. We therefore examined hydrogeological success, i.e. groundwater-surface water interactions, before and after the restoration of an urban stream and compared results to streams in natural and near-natural conditions. Results indicated that in the Chriesbach, groundwater-surface water interactions after restoration increased due to the installation of gravel islands. Additional analyses of the data in the future may allow estimates of the actual flux sizes of surface water downwelling into the gravel islands.

Future research should focus on investigating, amongst other parameters, the hydrogeological success of river restorations. Suitable methods for investigating the hydrogeological success in gaining and losing conditions is the $\mathrm{PAB}$ approach which applies passive (P) and active (A) distributed temperature sensing (DTS) to a buried (B) fibre-optic cable. Admittedly, it would be impossible to install a fibre-optic cable in or on the streambed of every restored stream. However, an installation in the streambed would only be necessary under losing conditions; in gaining streams, a simple installation on the streambed would suffice. These methods could then be employed only in selected case studies to help elucidate which restoration measures improve hydrogeological conditions and under which circumstances. In this way, future restoration projects could be optimized towards costeffectiveness and efficiency in re-establishing vertical connectivity, which would help to increase the overall effectiveness of river restorations.

Author contributions. A.-M. Kurth designed and performed the experiments; there was a continuous discussion about the contents with C. Weber and M. Schirmer. A.-M. Kurth prepared the manuscript with contributions from all authors.

Acknowledgements. This work was funded by the Competence Centre Environment and Sustainability (CCES) of the ETH domain in the framework of the Restored Corridor Dynamics (RECORD) project, the follow-up project RECORD Catchment, Swiss Experiment, and AQUALINK International Leibniz Graduate School. The authors wish to thank Hannah Cloke for editing the manuscript and Stefan Krause, Nick van de Giesen, Marc Walther, and the anonymous referee for their assistance in improving the manuscript.

Edited by: H. Cloke

\section{References}

Anderson, M. P.: Heat as Ground Water Tracer. Ground Water, 43, 951-968, doi:10.1111/j.1745-6584.2005.00052.x, 2005.

Andrea, F., Gschöpf, C., Blaschke, A. P., Weigelhofer, G., and Reckendorfer, W.: Ecological niche models for the evaluation of management options in urban floodplain-conservation vs. restoration purposes. Environ. Sci. Pol., 34, 79-91, doi:10.1016/j.envsci.2012.08.011, 2012.

Bencala, K. E.: Hyporheic exchange flows, in Anderson, M., ed. Encyclopedia of Hydrological Sciences, v.3., part 10, chapter 113, New Jersey, John Wiley and Sons, 1733-1740, 2005.

Boulton, A. J., Findlay, S., Marmonier, P., Stanley, E. H., and Valett, H. M.: The functional significance of the hyporheic zone in streams and rivers, Ann. Rev. Ecol. Syst., 29, 59-81, doi:10.1146/ANNUREV.ECOLSYS.29.1.59, 1998.

Briggs, M. A., Lautz, L. K., McKenzie, J. M., Gordon, R. P., and Hare, D. K.: Using high-resolution distributed temperature sensing to quantify spatial and temporal variability in vertical hyporheic flux, Water Resour. Res., 48, W02527, doi:10.1029/2011WR011227, 2012.

Butturini, A., Bernal, S., Hellin, C., Nin, E., Rivero, L., Sabater, S., and Sabater, F.: Influences of the stream groundwater hydrology on nitrate concentration in unsaturated riparian area bounded by an intermittent Mediterranean stream, Water Resour. Res., 39, 1110-1123, doi:10.1029/2001WR001260, 2003.

Cartwright, I., Hofmann, H., Gilfedder, B., and Smyth, B.: Understanding parafluvial exchange and degassing to better quantify groundwater inflows using ${ }^{222} \mathrm{Rn}$ : The King River, southeast Australia, Chem. Geol., 380, 48-60, doi:10.1016/j.chemgeo.2014.04.009, 2014. 
Cook, P. G.: Estimating groundwater discharge to rivers from river chemistry surveys, Hydrol. Process., 27, 3694-3707, doi:10.1002/hyp.9493, 2013.

Doering, M., Blaurock, M., and Robinson, C. T.: Landscape transformation of an Alpine floodplain influenced by humans: historical analyses from aerial images, Hydrol. Process., 26, 33193326, doi:10.1002/hyp.8374, 2012.

EU WFD - European Commission Directive 2000/60/EC of the European Parliament and of the council of 23 October 2000 establishing a framework for the Community action in the field of water policy, Off. J. Eur. Commun., L327, L327/1-L327/72, doi:10.2779/75229, 2000.

Filoso, S. and Palmer, M. A.: Assessing stream restoration effectiveness at reducing nitrogen export to downstream waters, Ecol. Appl., 21, 1989-2006, 2011.

Findlay, S.: Importance of surface-subsurface exchange in stream ecosystems: The hyporheic zone, Limnol. Oceanogr., 40, 159164, 1995.

Fuller, C. C. and Harvey, J. W.: Reactive uptake of trace metals in the hyporheic zone of a mining-contaminated stream, Pinal Creek, Arizona, Environ. Sci. Technol., 34, 1150-1155, doi:10.1021/es990714d, 2000.

Gilvear, D. J., Casas-Mulet, R., and Spray, C. J.: Trends and issues in delivery of integrated catchment scale river restoration: lessons learned from a national river restoration survey within Scotland, River Res. Appl., 28, 234-246, doi:10.1002/rra.1437, 2012.

Gooseff, M. N., McKnight, D. M., Lyons, W. B., and Blum, A. E.: Weathering reactions and hyporheic exchange controls on stream water chemistry in a glacial meltwater stream in McMurdo Dry Valleys, Water Resour. Res., 38, 15-1-15-17, doi:10.1029/2001WR000834, 2002.

Haase, P, Hering, D., Jähnig, S. C., Lorenz, A. W., and Sundermann, A.: The impact of hydromorphological restoration on river ecological status: a comparison of fish, benthic invertabrates, and macrophytes, Hydrobiologia, 704, 475-488, doi:10.1007/s10750-012-1255-1, 2013.

Hannah, D. M., Malcolm, I. A., and Bradley, C.: Seasonal hyporheic temperature dynamics over riffle bedforms, Hydrol. Process., 23, 2178-2194, doi:10.1002/hyp.7256, 2009.

Hoehn, E., von Gunten, H. R., Stauffer, F., and Dracos, T.: Radon222 as Groundwater Tracer. A Laboratory Study, Environ. Sci. Technol., 26, 734-738, doi:10.1021/es00028a010, 1992.

Jähnig, S. C., Lorenz, W., Hering, D., Antons, C., Sundermann, A., Jedicke, E., and Haase, P.: River restoration success: a question of perception. Ecological Applications, 21, 2007-2015, doi:10.1890/10-0618.1, 2011.

Kurth, A.-M.: Investigation of Groundwater-Surface Water Interactions with Distributed Temperature Sensing (DTS), Ph.D. thesis, University of Neuchâtel, 2015.

Kurth, A.-M. and Schirmer, M. Thirty years of river restoration in Switzerland: implemented measures and lessons learned, Environ. Earth Sci., 72, 2065-2079, doi:10.1007/s12665-014-3115-y, 2014.

Kurth, A.-M., Dawes, N., Selker, J., and Schirmer, M.: Autonomous distributed temperature sensing for long-term heated applications in remote areas, Geosci. Instrum. Method. Data Syst., 2, 71-77, doi:10.5194/gi-2-71-2013, 2013.

Louhi, P., Mykrä, H., Paavola, R., Huusko, A., Vehanem, T., MäkiPetäys, A., and Muotka, T. Twenty years of stream restoration in
Finland: little response by benthic macroinvertebrate communities, Ecol. Appl., 21, 1950-1961, 2011.

Maher, M., Nevill, J., and Nichols, P.: Improving the legislative basis for river management in Australia-Stage 2 Report. Land and Water Australia, Canberra, available at: http://lwa.gov.au/files/ products/national-rivers-consortium/pn30264/pn30264.pdf (last access: 25 September 2014), 2009.

Malard, F., Tockner, K., Dole-Olivier, M.-J., and Ward, J. V.: A landscape perspective of surface-subsurface hydrological exchanges in river corridors, Freshw. Biol., 47, 621-640, doi:10.1046/j.1365-2427.2002.00906.x, 2002.

Mendiondo, E. M.: Challenging issues of urban biodiversity related ecohydrology, Braz. J. Biol., Supplement, 68, 983-1002, doi:10.1590/S1519-69842008000500007, 2008.

Norman, F. A. and Cardenas, M. B.: Heat transport in hyporheic zones due to bedforms: An experimental study, Water Resour. Res., 50, 3568-3582, doi:10.1002/2013WR014673, 2014.

Palmer, M. A., Bernhardt, E. S., Allan, J. D., Lake. P. S., Alexander, G., Brooks, S., Carr, J., Clayton, S., Dahm, C. N., Follstad, Shah, J., Galat, D. L., Loss, S. G., Goodwin, P., Hart, D. D., Hassett, B., Jenkinson, R., Kondolf, G. M., Lave, R., Meyer, J. L., O’Donnell, T. K., Pagano, L., and Sudduth, E.: Standards for ecologically successful river restoration. J. Appl. Ecol., 42, 208-217, doi:10.1111/j.1365-2664.2005.01004.x, 2005.

Read, T., Bour, O., Selker, J. S., Bense, V. F., Le Borgne, T., Hochreutener, R., and Lavenant, N.: Active-Distributed Temperature Sensing to continuously quantify vertical flow in boreholes, Water Resour. Res., 50, 3706-3713, doi:10.1002/2014WR015273, 2014.

Robinson, C. T. and Doering, M.: Spatial patterns in macroinvertabrate assemblages in surface-flowing waters of a glacially-influenced floodplain, Aquat. Sci., 75, 373-384, doi:10.1007/s00027-012-0283-2, 2013.

Selker, J. S., Thévenaz, L., Huwald, H., Mallet, A., Luxemburg, W., van de Giesen, N., Stejskal, M., Zeman, J., Westhoff, M., and Parlange, M. B.: Distributed fibre-optic temperature sensing for hydrologic systems, Water Resour. Res., 42, W12202, doi:10.1029/2006WR005326, 2006a.

Selker, J., van de Giesen, N., Westhoff, M., Luxemburg, W., and Parlange, M. B.: Fibre optics opens window on stream dynamics, Geophys. Res. Lett., 33, L24401, doi:10.1029/2006GL027979, 2006b.

Shope, C. L., Constantz, J. E., Cooper, C. A., Reeves, D. M., Pohll, G., and McKay, W. A.: Influence of large fluvial islands, streambed, and stream bank on surface water-groundwater fluxes and water table dynamics, Water Resourc. Res., 48, W06512, doi:10.1029/2011WR011564, 2012.

Steele-Dunne, S. C., Rutten, M. M., Krzeminska, D. M., Hauser, M., Tyler, S. W., Selker, J., Bogaard, T. A., and van de Giesen, N. C.: Feasibility of soil moisture estimation using passive distributed temperature sensing, Water Resour. Res., 46, W03534, doi:10.1029/2009WR008272, 2010.

Sudduth, E. B., Hassett, B. A., Cada, P., and Bernhardt, E. S.: Testing the field of dreams hypothesis: functional responses to urbanization and restoration in stream ecosystems, Ecol. Appl., 21, 1972-1988, 2011

Swiss Water Protection Act, WPA, Swiss Federal Act of 24 January 1991 on the Protection of Waters, 814.20, available at: 
http://www.admin.ch/ch/e/rs/c814_20.html, last access: 17 July 2014.

Thorp, J. H., Thoms, M. C., and Delong, M. D.: The riverine ecosystem synthesis: Biocomplexity in river networks across space and time, River Res. Appl., 22, 123-147, doi:10.1002/rra.901, 2006.

Trauth, N., Schmidt, C., Vieweg, M., Oswald, S. E., and Fleckensteiin, J. H.: Hydraulic controls of in-stream gravel bar hyporheic exchange and reactions, Water Resour. Res., 51, 22432263, doi:10.1002/2014WR015857, 2015.

Tyler, S. W., Selker, J. S., Hausner, M. B., Hatch, C. E., Torgersen, T., Thodal, C. E., and Schladow, S. G.: Environmental temperature sensing using Raman spectra DTS fibre-optic methods, Water Resour. Res., 45, W00D23, doi:10.1029/2008WR007052, 2009.

Unland, N. P., cartwright, I., Andersen, M. S., Rau, G. C., Reed, J., Gilfedder, B. S., atkinson, A. P., and Hofmann, H.: Investigating the spatio-temporal variability in groundwater and surface water interactions: a multi-technique approach, Hydrol. Earth Syst. Sci., 17, 3437-3453, doi:10.5194/hess-17-3437-2013, 2013.
Violin, C. R., Cada, P., Sudduth, E. B., Hassett, B. A., Penrose, D. L., and Bernhardt, E. S.: Effects of urbanization and urban stream restoration on the physical and biological structure of stream ecosystems, Ecol. Appl., 21(6), 1932-1949, 2011.

Wondzell, S.: The role of the hyporheic zone across stream networks, Hydrol. Process., 25, 3525-3532, doi:10.1002/hyp.8119, 2011.

Wortley, L., Hero, J.-M., and Howes, M.: Evaluating ecological restoration success: a review of the literature, Restor. Ecol., 21, 537-543, doi:10.1111/rec.12028, 2013. 